\title{
Philippines: \\ The Role of Bae in Resolving Conflict and Maintaining Tribal Peace and Order
}

\author{
Primitivo III C. RAGANDANG \\ Sulpecia L. PONCE
}

\begin{abstract}
This exploratory research investigates the role of baes (women members of the tribal council) in the traditional system of conflict resolution, as well as in maintaining tribal peace and order. With the Higaunon tribe of Barangay Kiabo, Malitbog, Bukidnon province, Philippines, as case in point, the data employed in this study include the responses of the members of the tribal council, especially of the baes. The study uses a qualitative approach and the data is interpreted using descriptive analysis. The study shows the historical account of the Higaunon tribe, including its patriarchal nature. It also discusses the qualifications, selection process, as well as koda (coding) given to the bae. The article then looks into the roles and responsibilities of the baes in the traditional conflict resolution of the tribe and the role they play in maintaining the peace and order of the tribe in general. Similar with their male counterparts, baes are being selected by the tribal chieftain. The tribal chieftain is also the one who assigns tasks to the baes while, in many instances, the baes serves as the record and tribal activity keepers, making it sure that

Primitivo III C. RAGANDANG tribal policies and affairs are observed properly.
\end{abstract} Mindanao State University lligan Institute of Technology Iligan City, Lanao del Norte, Philippines Email: prime.tivo@gmail.com

\section{Sulpecia L. PONCE \\ Mindanao State University \\ lligan Institute of Technology \\ lligan City, Lanao del Norte, Philippines \\ Conflict Studies Quarterly \\ Issue 27, April 2019, pp. 59-69}

DOI:10.24193/csq.27.4

Published First Online: 01/04/2019
Keywords: bae, Higaunon, traditional conflict resolution, tribe, peace.

\section{Background of the Study}

While there is a bulk of studies, advocacies and even foreign funding focused on protecting the rights of indigenous peoples (IPs), only a few researches were focused on how women are treated and afforded the role in resolving the tribal conflicts, as well as maintain peace in their own tribal communities. As the international community promotes the protection and preservation 
of the indigenous culture of the lumads, including its system of conflict resolution, Philippine law maintains that lumads "shall have the right to use their own commonly accepted justice systems, conflict transformation institutions, peace building processes or mechanisms and other customary laws and practices within their respective communities and as may be compatible with the national legal system and with internationally recognized human rights" (Indigenous Peoples Rights Act, Republic Act 8371, s. 11). As this traditional system of conflict resolution is being transferred from one generation to the next (but has not evolved through the needs of time), it is but vital to explore the system and test out if it conforms to the contemporary standards of human rights. In Mindanao, indigenous peoples are commonly known as lumad, the nearest English translation of the term being native. To some, the term bears negative connotation which in effect becomes a subject of cultural prejudices. Rodil (1994) asserted that lumad is a Cebuano Bisayan word meaning indigenous which has become the collective name for the 18 ethno-linguistic groups, namely Ata, Bagobo, Banwaon, B'laan, Bukidnon, Dibabawon, Higaunon, Kalagan, Mamanwa, Mandaya, Mangguwangan, Manobo, Mansaka, Subanon, Tagakaolo, T'boli, Tiruray and Ubo. Other terms that may be used interchangeably to refer to IPs include indigenous cultural communities, Filipino cultural communities and early Filipino communities.

The central emphasis of this paper is to explore the role of baes as women members of the tribal council in the traditional system of conflict resolution of the Higaunonsin Kiabo, Malitbog, Bukidnon.

\section{Objectives}

This study explores the role of baes (women members of the tribal council) in the indigenous system of resolution of conflicts, as well as in maintaining tribal peace and order in general, with the Higaunon tribe of Barangay Kiabo, Malitbog, Bukidnon province (Philippines) as the case in point.

Specifically, this paper sought to explore the following objectives:

1. To identify the historical account of the Higaunon tribe in Bukidnon;

2. To analyze the qualifications, selection process, as well as koda (coding) given to the baes;

3. To investigate the roles and responsibilities of the baes in the indigenous system of resolution of conflicts, as well as in maintaining tribal peace and order in general.

\section{Research Setting}

The research is conducted in Kiabo, Malitbog, Bukidnon. The municipality of Malitbog is one of the 22 municipalities of the province of Bukidnon. Located at the northern most part of the province, it lies between parallel $8^{\circ} 25^{\prime} 35^{\prime \prime}$ and $8^{\circ} 36^{\prime} 8^{\prime \prime}$ North Latitude and Meridians $124^{\circ} 49^{\prime} 39^{\prime \prime}$ and $125^{\circ} 11^{\prime} 39^{\prime \prime}$ East Longitude. Malitbog is a landlocked 
municipality bounded on the North by the Municipality of Claveria and on the western side by Tagoloan - both of which are part of Misamis Oriental. Bounding it on its southern part are the municipalities of Manolo Fortich and Impasug-ong of Bukidnon while on its eastern side is the municipality of Esperanza, Aguzan Del Sur. The municipality is roughly 40 kilometers away from the regional capital Cagayan de Oro City and about two and one-half-hour-ride from City of Malaybalay, Provincial Capital (Malitbog Municipal Planning Office, 2010). Barangay Kiabo is a 90-minute-single-motor ride from the town proper of Malitbog municipality.

Malitbogis subdivided into 11 barangays, one of which is Kiabo. Its total land area is approximately 58, 185 hectares which is about $7.02 \%$ of the total land area of the province of Bukidnon, based on Administrative/Thematic maps of DENR-CENRO Office No. B-340 and is certified by Land Management Bureau. From Barangay San Luis and Kiabo going southwestern part, it is covered with up to 50 percentof slope and above with an elevation of 200 to 1,000 meters above sea level (Sensagent, n.d.). A major portion of this area has severe erosion with only small area with slight erosion based on thematic map (Malitbog Municipal Planning Office, 2010).

In particular, Kiabois located at the northernmost part of Malitbog, it lies between parallel $8^{\circ} 33^{\prime}$ and $8^{\circ} 36$ North Latitude and $124^{\circ} 54^{\prime}$ and $125^{01^{\prime}}$ East Longitude. It is bounded in the North by the municipality of Claveria, Misamis Oriental; on the South, by San Luis and Omagling; on the East, San Luis and on the West, Mindagat. It is about 30 minutes ride from Poblacion covering roughly 13 kilometres, and about one and one-half ride from Cagayan de Oro City (Malitbog Municipal Planning Office, 2009).

\section{Methodology}

The study uses the case study approach. Field visits were employed in this study wherein focused group discussions (FGD) and in-depth personal interview took place. The case study method, according to McNabb (2013), is often intensive studies of one or a few exemplary individual, event, programs, institutions, and organisations. Discussing the case method as one of the three qualitative approaches to research, the 1993 argument of Arenson (as cited by McNabb, 2013) considers it as an appropriate research method when a case involves some noteworthy success or failure.

A triangulation of data gathering methods was utilised in this study, consisting of key informant interview (KII), focus group discussion (FGD) and direct and participant observation. Firstly, a KII was conducted in the community using a semi-structured interview which, as Eriksson \& Kovalainen (2008) pointed out, questions may vary in wording or sequence but is anchored in a few guiding predetermined questions and themes that also gave room for relevant topics or concerns. Hybels and Weaver (2001) defined interview as a series of questions and answers usually exchanged between two people which have the purpose of getting and understanding information about a 
particular subject or topic. Early on the research process, a thoughtful choice was made to interview only five key informants in each organisation, choosing those with most engagement with the group.

Secondly, FGD was conducted with members of the tribal council. Hybels and Weaver (2001) defined FGD as a forum where ideas are proposed and then modified in response to the group's feedback. It is a way for everyone to participate and be heard. Using an FGD guide, it was conducted inside the tribe. Direct and participant observation is the third method used in this study wherein fieldworks were conducted. Fetterman (1989) stressed that fieldwork is the key activity in all qualitative research designs which, as added by Ryan and Bernard (2003), allows the researcher to get close to people, making them comfortable enough to permit the researcher to observe and record observations about their lives. Upon completion of necessary research data gathering protocols, formal data gathering took place in the community. Key informant interview, focused group discussions and participant observation were scheduled accordingly, mainly based on the convenient of informants.

This paper is limited to the case of the Higaunon tribe in Kiabo, Malitbog, Bukidnon. Due to the absence of a comprehensive record of conflict resolution in the tribe, it is not bounded to a particular number of years but is dependent on the cases that can still be recalled by the tribal council members. In gathering data of this paper, FGD, personal and in-depth interview were the major tools. In conducting the FGD, personal and indepth interview, the researcher was guided by the following process:

1. A communication requesting consent from the Barangay Captain of Kiabo, Malitbog, Bukidnon was prepared by the researcher. Another letter requesting permission and asking security support from the Municipal Mayor of Malitbog, Bukidnon was prepared also.

2. With the letter, the researcher visited the Malitbog Municipal Hall and asked records about the Higaunons tribe situated in Kiabo, Malitbog, Bukidnon.

3. With the help of the Barangay Council of Barangay Kiabo, the researcher visited the area to become acquainted and make a preliminary interview. A cordial and pleasant atmosphere was established between the researcher and the respondents.

4. Upon the approval to conduct research from the Barangay Captain of Barangay Kiabo, and the permission from the Mayor's office for security assistance, the researcher visited the locale again and conducted the personal interviews and FGD.

5. Prior to the interview and FGD, the researcher introduced himself and the rationale of the activity. Cebuano dialect was used by the researcher in the entire process. The respondents are assured that nothing would place them in any compromising or embarrassing situation and that all their responses would be treated with utmost secrecy. Moreover, note taking and a tape recorder was used in order to have a complete documentation for the responses of the respondents. 
6. After the respondents answered all the questions, the researcher closed the interview with gratefulness for the information obtained and for the time spared by the respondents.

As part of the limitations of this paper, the researcher notes that this research only applies to the case of the Higaunon tribe in Kiabo, Malitbog, Bukidnon. Though there could be possible similarities with their system and with the system of other tribal communities, it is important to note that this paper focuses only on the case of the tribe mentioned above.

Among other factors, one of the main reasons in selecting the subject of this research is the unique cultural identity that this tribe possesses up to these days. They are endowed with a unique cultural identity which identifies the original and pre-colonial Filipino cultural heritage. Such culture is transferred from one generation to another (generally through oral tradition); it maintains the peace and order of tribe and it is seen as a strong institution that is worthy for academic attention.

\section{Results and Discussion}

This section presents and interprets the data gathered through key informant interview (KII), focus group discussion (FGD), and direct and participant observation.

\section{Historical account of the Higaunon Tribe in Bukidnon}

The province of Bukidnon is generally the home of more than 20 different indigenous communities. One of the most dominant of these tribes is the Higaunons. Aside from Bukidnon, while maintaining their traditional culture and practices, it is apparent that indigenous communities settle in the hinterlands, far from the undeviating upshot of technological advancement. Such scenario is not a result of an overnight mountaineering of IPs but is the result of past governmental policies and other socio-economic circumstances that leads IPs to move to the hinterlands.

Written accounts suggest that the term Higaonon is a combination of the root words higa (which means to live, to reside or to lay in bed), gaon (which means mountain) and onon which means people (Advocacy of Tribal Organizations and Networks, Inc., 2019). Therefore, people who live in the mountains. As written in the Barangay Development Plan available in Kiabo Barangay Hall (and as validated by the respondents), Kiabo was once a thickly forested area, inhabited by few families belonging to the Higaunon tribe. Etymologically, the village got its name from their oral history which says that once there was a villager who "miligosa abo" or "bathed in ashes". Since then, the village noted for the word " $a b o$ " or ash and was eventually named 'Kiabo' through RA 3590, and now is the home of many Higaunons, one of the lumads or indigenous peoples in Mindanao.

Indigenous peoples (IPs) principally refer to pre-colonial inhabitants of the Philippines and their descendants who have resisted assimilation or acculturation, with their tradi- 
tional systems, practices and beliefs remaining relatively intact (Tri-people Consortium for Peace, Progress and Development in Mindanao, 1998). Similarly, the Indigenous Peoples Rights Act (IPRA) of 1997 define IPs as a group of people who, through resistance to political, social and cultural inroads of colonization, non-indigenous religions and culture, became historically differentiated from the majority of Filipinos. Moreover, Rule 2, Section 1 (l) of the Indigenous Peoples Rights Act or Republic Act 8371 states that "indigenous peoples have continuously lived as organized community on communally bounded and defined territory, and who have, under claims of ownership since time immemorial, occupied, possessed customs, tradition and other distinctive cultural traits".

Similar with other societies, such as the Roma communities in Romania (Sandu, 2018) who possess indigenous mechanisms in resolving conflicts, long before the advent of foreign invaders in the country, early Filipino communities are already governed by laws vis-à-vis the protection of the people of their tribal communities. One of these practices that are still present up to these days is the traditional system of paghusay (resolving conflict using traditional tribal laws). In the course of paghusay conducted by a datu, rajah, or sultan, with the advice from the council of elders, the people in the village (locally known as balangay, which refers to a small boat by which ancient villagers use to traverse) knows that no person would be sentenced without due process of tribal law. Agoncillo and Guerrero (as cited by Bederio, Dela Rosa, Funtecha, Gicain, and Mendoza, 2004) affirm this assertion:

Because disputes are inevitable in any society, the early Filipinos also had their own judicial processes. Generally, conflicts were settled peacefully through a court composed of the datu as judge and the village elders as jury. On the other hand, conflicts arising between subjects of different barangays were resolved by arbitration through a council of elders coming from neutral barangays. Trials were held publicly and were conducted without any delay the accused and the accuser faced each other accompanied by their respective witnesses (p. 20).

Hesitant to adopt the new political system and religion that the Spaniards introduced to the country in the 16th century, some of the lumads (Filipino indigenous cultural communities) from the various parts of the archipelago moved to the mountains and continued their aboriginal practices, including their indigenous political structure. Among other structure, the lumads has established a system of conflict transformation (locally known as paghusay for the Higaunon lumads in Mindanao), alleviating tribal justice and the sanctity of tawhanongkatungod (human rights).

\section{Qualifications, selection process, and koda (coding) given to the baes}

The lumads of Mindanao are one of the IPs who are recognized as the true natives of the islands, who, at one time, occupied and controlled a substantial portion of Mindanao and Sulu archipelago (Tri-People Consortium for Peace, Progress and Development 
of Mindanao, 1998). The Advocacy of Tribal Organizations and Networks, Inc. (2019) added that before being conquered, they preserved their own lives and clung to their communal views of the land, to their co-operative work exchanges, communal ritual, dances, songs and folklores. They revered their own God. Their animistic worship, however, could not have persisted had it not been for the peaceful and non-imposing stance of Islam. A classic manifestation of this is the non-Islamization of the Tiruray and the Manobo, who were part of the common borders and in constant trade with the more socially cohesive Muslim Maguindanao.

Mercado (1993) argued that, unlike the early IPs who embraced Christianity, the lumads have retained their original primal religion because they refused to accept neither Islam nor Christianity at the early times of colonisation. At any rate, a plenty of lumads to date are already converted to either Islam or Christianity, though they continue to practice their indigenous religious activities (Ragandang, 2017).

The Higaunon is one of the lumads in the mountainous areas of Northern Mindanao. Most Higaunons still have a traditional way of living. Farming is the most important economic activity for them. The belief in the power of the spirits of ancestors and in the influence of more than one god is strongly rooted in the hearts and minds of many Higaunons. Most Higaunons still have a strong belief in the existence of gods and spirits. The 'upper god' is HalangdongMagbabaya, the creator of all aspects of life. There are several 'lower gods'. Each 'lower god' has dominion over a specific part of the natural environment. There is a lower god (Igbabasok) who has dominion over the farms, a lower god (Pamahandi) who has dominion over treasures and properties, a lower god (Bulalakaw) who has dominion over the waters and fishes and there is a lower god (Panalagbugta) who has dominion over lands (Valmores, 2008). This belief, called "animism", influences the Higaunon people deeply. They believe that all problems like illnesses, bad harvests and even death are due to their failure to satisfy the spirits (Valmores, 2008). They are the pioneering settlers of Cagayan de Oro City in Northern Mindanao. They found their way to the mountainous areas of Misamis Oriental, Bukidnon and Agusan Provinces as they resisted the acculturation brought about by the arrival of colonizers. In Malitbog, Bukidnon, the majority of them settled in the most mountainous areas which bound the municipality from the provinces of Misamis Oriental, Agusan del Norte and the municipality of Impasug-ong, Bukidnon. One of these mountains where the Higaunons inhabit is Kiabo (Ragandang, 2017).

Serving as a group of rulers in the tribe, the tribal council is headed by the Datu or the chieftain. In the case of the Higaunons in Kiabo, it is the tribal chieftain who chooses who can be a bae. In general, selectionis based on the discretion of the tribal chieftain. There is no set of qualifications for a woman to be a bae; after all, selection is mainly at the discretion of the tribal chieftain. When selected to be a bae, there is no maximum age limit to serve in the tribal council, as long as the person can still function well with 
her duties as bae. While there is no written qualifier to be a bae, possessing the ability of being a respectable person (mayrespetosakaugalingon) is an unwritten but deemed requirement for one to be a bae.

Once a bae is selected by the Chieftain, she is then invited to join the meetings of the tribal council. She is also entitled to wear the uniform that her male counterparts are wearing; which is generally similar, including colors and design,except that for a bae, which is a skirt. Based on the bae's known skills, the tribal chieftain generally assigns tasks to the bae based on it. Most of the time, the bae serves as note taker of minutes in the conflict resolution processes in the tribe.

When a bae is selected, the chieftain (along with her fellow members of the tribal council) will assign a koda (code) for her. This code will serve as her tribal name and is always prefixed with "Bae". The selection of code is not a simple activity; it requires a discussion among members of the tribal council and must fit the talent, ability or personality of the bae. For instance, one of the baes is coded as Bae Mig-ayuna because she is known of being generally supportive and that, among other traits, her being supportive stands out. Ming-ayuna translates to English as "being supportive" from the indigenous term "uyon" which means "to support".

The Advocacy of Tribal Organizations and Networks, Inc. (2019) stressed that in Higaunon oral tradition, their common roots is from the mother of the post-deluge generation, Apo Entampil, Apo of all Apo - also known as Gahumon or Pinaiyak, mentioned of the following lines:

"Ngani Kang Ko Bahi Sa Lumbay Ko, Panglipaklipak, Ko, Pulo, Ko Kakayo-A ngani Kang Ko Maama Sa Lumbay Ko, Pandayaon, Ag-Asawahon Ko. [If it's going to be a female, I'll just throw it to the forest or top of the tree but if it is going to be a male, I will make him my husband].

While the inclusion of women in the conflict resolution in the tribe manifests gender equality, the existence of the "third sex" is discouraged in the tribe. Datu Sabangan (personal communication, 2012) asserted that relationships between lesbians, gays, bisexuals and transsexuals (LGBT) are prohibited; if happened, it is believed that lightning may strike to the wrongdoers (litian).

\section{Roles and responsibilities of the baes in the indigenous system of resolution of conflicts, as well as in maintaining tribal peace and order in general}

Currently, there are 24 members of the tribal council of the Higaunon tribe of Kiabo, Malitbog, Bukidnon; eighteen (75\%) of them are datus (men) while six (25\%) are baes (women), as follows: 
Table 1. Baesas Women Members of the Tribal Council with Their Corresponding Koda (Code or Tribal Name) and Designation

\begin{tabular}{ll}
\hline \multicolumn{1}{c}{ Koda or Tribal Name } & \multicolumn{1}{c}{ Designation/ Expertise } \\
Bae Mig-ayuna & The Supporter \\
Bae Mangangapog & The Ritual Expert \\
\hline Bae Makabulig & The Council Treasurer \\
Bae Dalangpanan & The Refuge \\
Bae Malagimo & The Companion \\
Bae Maluluy-on & The Merciful \\
\hline
\end{tabular}

Specifically, the baes serve as note taker in the course of conflict resolution for cases submitted by residents to the tribal council for possible resolution. These cases range from common social discords such as misunderstandings between couples and to grave crimes such as killings. In resolving these cases, it is the chieftain that presides. If the chieftain requests for the opinion of the bae in weighing cases, then the bae can also give her opinion about the case.

Not only in taking part in the indigenous ways of conflict resolution, the baes also play a role in maintaining peace and order of the tribe in general. Baes help in maintaining the orderly conduct of weekly marketplace in the community. In order to avoid traffic jam, they are the ones who make it sure that vendors are cleared from occupying the roads for jeepers and other vehicles. In a personal interview with Datu Sabangan, he asserted that even before, women were treated equally. Though there are only six women members in the tribal council, it does not mean inferiority of treatment towards women. He added the case of Bae Ming-ayuna, the incumbent secretary of the tribal council, who once become the Chief of Civilian Volunteer Organization (CVO) in the tribe, a group which is meant to assist barangay officials in maintaining peace and order in the community; she was delegated by the barangay council. During the personal interview with Bae Ming-ayuna, she said that they were treated fairly by their male counterparts. They do not feel any discrimination. As a matter of fact, female dominance happened when she became the Chief of CVO in their tribe. The barangay chairman delegated her along with his team which was composed mainly of men. During her tenure, peace and order was maintained in the tribe. Also, they were able to impose authority though it was for the first time that the tribe got a female CVO Chief.

Relative to their role in resolving conflicts traditionally, one of the baes suggested an effective way of maintaining peaceful communities by imposing curfew in the tribe. Bae Mig-ayuna reiterated that in order to maintain a peaceful tribe, especially in the evening, she lobbied for the implementation of curfew among minors in the tribe. As a result, crimes decreased. The practice of observing curfew is now being replicated by other nearby communities. 
Positioned like a mother in a family, the baes in the tribal council also are the one who make it sure that tribal festivals and rituals and observed timely and properly. For instance, the baes are the ones who remind the chieftain in the conduct of the annual singampo, a yearly ritual in the tribe conducted every January to thank the previous year and welcome the New Year. More so, the bae also helps in translating the pandalawit (ritual chants) so that the non-native speakers in the tribe will understand the chants said in the rituals.

Such case manifests that, indeed, the Higaunon tribe of Kiabo, Malitbog, Bukidnon has fair treatment towards female. Though patriarchy is seen in the sense of more number of men in the tribal council, the respondents made it clear that it does not mean any inferior treatment towards women. This is also a good manifestation of gender sensitivity of the tribe. In combatting towards gender equality, the United Nations (UN) religiously give attention to the matter by considering such issue in one of the then Millennium Development Goals (MDGs) and now Sustainable Development Goals (SDGs). Among other goals, gender equality places a special part in the UNs advocacy for a better world. Moreover, the tribe has negative treatment towards third sex. It is considered a taboo. As numerous groups among the civil society advocate towards impartial treatment (both legal and social senses), there is also a need for a deep discussion with the tribal council as on how to properly deal with issues involving the presence of third sex in the tribe.

\section{Conclusions}

This research has presented the role of baes (women members of the tribal council) in the traditional system of resolution of conflicts, as well as in maintaining tribal peace and order in general, with the Higaunon tribe of Barangay Kiabo, Malitbog, Bukidnon province, Philippines as case in point. The Higaunons, therefore, possess a traditional system of conflict resolution to maintain the welfare of its tribal members. In resolving such conflicts, the tribal council employs indigenous systems which involve both men and women members. Baes, as women members of the tribal council, generally serves as note taker of what transpired in the conflict resolution process. Selection of baes is a discretionary function of the tribal chieftain. He is also the one who determines the qualification and traits of baes to be included in the tribal council. While there is no written rule on the selection of baes, it is a generally accepted principle that to be a bae means to possess the traits of being respected by the tribal community. Aside from their role in the indigenous conflict resolution activities, bae also play an important role in maintaining peace and order in the tribe, in general. They help their male counterparts in securing the tribe by suggesting helpful strategies in maintaining peaceful tribes, as well as make it sure that tribal rituals are celebrated properly. This practice of women inclusion in the tribal council amidst the highly patriarchal indigenous communities in Mindanao is a good manifestation of gender sensitivity of the tribe, thus supporting the United Nations' religious campaign of giving attention to women's role in making 
more resilient communities. Thus, the role of women in the Higaunon tribal council of Kiabo, Bukidnon is an insightful practice to ponder: that while conflict is a universal phenomenon, and that indigenous practices are still employed by tribal communities, and so is the role of women in making such indigenous practices even more effective and sustainable.

\section{References}

1. Advocacy of Tribal Organizations and Networks, Inc. (2019). History of the Higaunon tribe. Advocacy of Tribal Organizations and Networks. Retrieved from http://atoniglob al.blogspot.com/p/about-us.html.

2. Bederio, C. L., Dela Rosa, S. J., Funtecha, H. F., Gicain, M. S. C., \& Mendoza, M. M. (2004). Philippine government and constitution. Bulacan: Trinitas Publishing, Inc.

3. Ryan, G. W., \& Bernard, H. R. (2003). Techniques to Identify Themes. Field Methods, 15(1), 85-109. DOI: https://doi.org/10.1177/1525822X02239569.

4. Eriksson, P., \& Kovalainen, A. (2008). Qualitative methods in business research. London: Sage Publishing.

5. Fetterman, D. M. (1989). Ethnography step by step. Newbury Park: Sage Publishing.

6. Hybels, S., \& Weaver, R. (2001). Communicating effectively. New York: McGraw-Hill.

7. Malitbog Municipal Planning Office (2010). Profile of the municipality of Malitbog. Malitbog: LGU-Malitbog.

8. McNabb, D. (2013). Research methods in public administration and nonprofit management. New York: Routledge.

9. Mercado, L. N. (1993). Elements of Filipino philosophy. Tacloban: Divine Word University Publications.

10. Ragandang, Primitivo III C. (2017). Philippines: The Indigenous Conflict Resolution Practices of the Higaunon Tribe. Conflict Studies Quarterly, 19, 65-84.

11. Rodil, B. R. (1994). The minoritization of the indigenous communities of Mindanao and the Sulu archipelago.Davao City: AFRIM.

12. Sandu, C. (2018). Romania: Traditional conflict resolution mechanism used by the Roma communities. Conflict Studies Quarterly, 22, 95-108. DOI: https://doi.org/10.24193/ csq.22.6.

13. Sensagent (n.d). Malitbog, Bukidnon. Sensagent. Retrieved from http://dictionary.sen sagent.com/Malitbog,\%20Bukidnon/en-en/.

14. Tri-People Consortium for Peace, Progress and Development of Mindanao (1998). Defending the land: Lumad and Moro peoples' struggle for ancestral domain in Mindanao. Manila: TRICOM.

15. Valmores, C. (2008). The Higaunon people of Northern Mindanao. Retrieved from http://www.philippines.hvu.nl/higaunon1.htm. 